\title{
Volunteer satisfaction in sports clubs: A multilevel analysis in ten European countries
}

\begin{abstract}
Regular voluntary engagement is a basic resource for sports clubs that may also promote social cohesion and active citizenship. The satisfaction of volunteers is an imperative factor in this engagement, and the purpose of this article is to explore individual and organizational determinants of volunteer satisfaction in sports clubs. Theoretically, our study builds on the actor-theory concept where volunteer satisfaction depends on subjective evaluations of expectations and experiences in a sports club ("logic of situation”), so that positive evaluations lead to higher satisfaction and, hopefully, retention of volunteers. This research used a sample of 8,131 volunteers from 642 sports clubs in ten European countries, and is the first analysis to combine determinants at the level of the club and the volunteer (multilevel). Results show that the most important determinants of satisfaction are the conditions of volunteering (recognition, support, leadership and material incentives) and the workload of volunteers. Surprisingly, club characteristics, size or having paid staff, are not significant determinants of volunteer satisfaction. The results of this analysis can assist more effective volunteer management in sports clubs that are facing challenges of individualization and professionalization.
\end{abstract}

Key words: volunteering, volunteer satisfaction, sports clubs, actor theory concept, multi-level approach 


\section{Introduction}

Volunteering is a key resource for the provision of affordable sports activities in sports clubs (Doherty, 2005). Furthermore, volunteering is also believed to have positive externalities both for the volunteers involved and for the wider society. On a group level, volunteers may experience high levels of social integration in their clubs because most sports clubs offer obliging sports communities (Elmose-Østerlund et al., 2019; Østerlund \& Seippel, 2013; Seippel, 2005). On a societal level, volunteering is believed to promote social cohesion and social trust in the broader community (Janssens \& Verweel, 2014; Putnam, 2000). Finally, many volunteers also gain experience in active citizenship due to the democratic decisionmaking structure of sports clubs (Ibsen et al., 2019; Nagel et al., 2015; Warren, 2001). In sum, successful volunteers tend to experience high levels of social integration and trust, and contribute to citizenship and democratic participation.

Modern societies are often diagnosed as individualistic with people that are more selfinterested consumers than citizens with moral responsibilities (Putnam, 2000). This further highlights the potential of volunteering as a contributor to a more cohesive society, at the same time, individuals' more fleeting commitment raises a challenge to clubs in recruitment and management of volunteers. Along with an individualized society, professionalization of sports clubs and the employment of paid staff may weaken the motivation for members to volunteer (Seippel, 2010). As a result, many sports clubs report to be struggling with the recruitment and retention of qualified volunteers, particularly in board positions (Breuer et al., 2017; Nichols, 2017). Against this background, the ways the sports clubs treat their volunteers and what they do to recruit and retain volunteers becomes increasingly important, and in this context, volunteer satisfaction becomes crucial. If the work of volunteers matches their expectations, the volunteers are more likely to be satisfied and to continue their engagement as well as to communicate positively about volunteering (e.g. Bang, 2015; Chelladurai, 2006; Doherty, 2005; Einolf, 2018; Schlesinger, Egli, \& Nagel, 2013, 2017; Schlesinger \& Nagel, 2018; 
Vecina, Chacón, Sueiro, \& Barrón, 2012). This raises the question as to how sports clubs can work to increase the satisfaction of their volunteers.

This paper aims to identify the individual (e.g. workload of volunteers, sociodemographics) and organizational factors (e.g. conditions for volunteering, club characteristics) relevant for volunteer satisfaction. Based on the multi-level model of sports clubs (Nagel, 2007; Nagel et al., 2015) we develop a differentiated view on determinants of volunteer satisfaction. The innovative multilevel analysis combines data from a club and a member survey to simultaneously investigate the relevance of volunteer management (e.g., specific measures to manage volunteers by improving the working conditions) and structural characteristics (e.g. size of the club, paid staff) to volunteer satisfaction. In addition, our study is the first to utilize data collected in ten different European countries.

\section{Conceptual background}

Multi-level framework

In order to develop a framework that can combine the individual, organizational and societal levels of volunteer satisfaction, it is appropriate to analyze sports clubs and their members as well as volunteers using the social theory of action (Coleman, 1986; Esser, 1993; Giddens, 1984). The basis of actor-theory is the assumption that social acting and social structures are in a constant reciprocal relation throughout time (Giddens, 1984). According to Esser (1993) and the concept logic of situation, we can assume that both the general societal context and specific organizational factors are relevant to the actions, decisions and evaluations of club members and volunteers (for sports clubs: Nagel, 2007; Nagel et al., 2015). In order to capture this complexity, we draw on a multi-level framework (see also Schlesinger and Nagel, 2013; Swierzy, Wicker \& Breuer, 2018; Wicker \& Hallmann, 2013) to examine how the engagement of sports club members as volunteers depends on individual characteristics (socio-demographic and volunteer-related factors), and the organizational determinants of the sports club (e.g. size, 
paid staff, specific measures to promote volunteering). The crux of the model is to combine factors at each level, and particularly to see how the subjective evaluations of the specific conditions of volunteering (e.g. support, recognition) are relevant to volunteer satisfaction.

\section{Concept of volunteer satisfaction}

Different authors have provided insights into the experience of volunteers by applying the concept of job satisfaction to the volunteering context (Bang, 2015; Costa, Chalip, Christine Green, \& Simes, 2006; Galindo-Kuhn \& Guzley, 2001; Schlesinger et al., 2013; Schlesinger et al., 2017). Here, job satisfaction refers to the emotional and cognitive evaluation of individuals' expectations and experiences of the work situation (Locke, 1969). If the volunteers evaluate certain conditions of volunteering in a positive way this leads to a higher satisfaction. This basic concept is in line with the theoretical idea of the logic of situation (see above).

While much volunteerism research has been dedicated to the antecedents and outcomes of volunteering, the experience of volunteering as indicated by volunteer satisfaction has been less researched (Wilson, 2012). In a literature review, Einolf (2018) provides an overview of studies that investigate volunteer satisfaction in different voluntary organizations (e.g. Finkelstein, 2008; Dwiggins-Beeler, Nencini, Romaioli, \& Meneghini, 2016; Spitzberg, \& Roesch, 2011), but relatively few studies on sports clubs were identified (e.g. Behrens, Emrich, Hämmerle, \& Pierdzioch, 2018; Schlesinger et al., 2013). Furthermore, the existing investigations usually focus on few particular determinants relevant to volunteer satisfaction.

Schlesinger et al. (2013) developed an empirically based typology of conditions relevant for the satisfaction of volunteers of sports clubs based on general multi-dimensional concepts of volunteer satisfaction (e.g., Galindo-Kuhn \& Guzley, 2001; Vecina et al., 2012). The most important factors were (see also Schlesinger, Klenk, \& Nagel, 2014): 1) task design; defined as challenging, autonomous, and interesting work, 2) leadership; described as receiving constructive feedback, information, and contact with club management, 3) support; described 
as assistance of other members, problems are taken seriously, and respectful treatment, 4) material incentives; described by some minor payment and fringe benefits, and 5) recognition; defined by appreciation of work, and acknowledgement. This specific concept for the context of volunteering in sports clubs has similar dimensions to those reported in studies on volunteering in other nonprofit organizations (e.g. Dwiggins-Beeler, et al., 2011; Nencini, et al., 2016).

\section{Individual and organizational factors of volunteer satisfaction}

In the following, we develop research questions based on our conceptual framework and current research. The existing studies in volunteerism research show that the conditions of volunteering are quite relevant, but also other individual and organizational factors might play a role for volunteer satisfaction. However, so far, no research has examined these factors simultaneously in a multilevel analysis by combining individual and organizational data from different countries.

Several studies have highlighted the importance of the organizational context of volunteering and the relevance of volunteers' expectations of working conditions for volunteer job satisfaction (Blackman \& Benson, 2010; Harman \& Doherty, 2014, Nencini et al., 2016). Hobson and Heler (2007) demonstrated that job assignment quality and treatment by staff is positively correlated with volunteer satisfaction. Farrell, Johnston and Twynam (1998) showed that communication with other volunteers, leaders' recognition of volunteers were significant predictors of volunteer satisfaction (see also Dwiggins-Beeler, et al., 2011). Costa et al. (2006) found that a sense of community among volunteers had a positive effect on job satisfaction. Moreover, perceived organizational support was found to be positively correlated to volunteer satisfaction (Stukas, Hoye, Nicholson, Brown, \& Aisbett, 2016). Schlesinger et al. (2013) showed that the more volunteers in sports club evaluate certain working conditions (task design, material incentives, leadership, support, recognition) in a positive way the more likely they 
report higher levels of satisfaction (also Schlesinger et al., 2017). Therefore, the question arises to what extent are the following working conditions of volunteering (perceived by the volunteers) relevant for volunteer satisfaction: task design, leadership, support, material incentives, workload and recognition?

Previous studies have found a relationship between time spent on volunteering and volunteer satisfaction. Volunteers who invest more hours in their voluntary activities are more satisfied and report a higher level of happiness (Dulin, Gavala, Stephens, Kostick, \& McDonald, 2012; Pauline, 2011). However, other studies have reported that a longer commitment to volunteering in an organization and a higher amount of time spent for volunteering result in higher expectations with regard to leadership and recognition (Schlesinger et al., 2013). This could have a negative effect on satisfaction. In contrast, there is no specific research about possible differences with regard to the satisfaction of volunteers in different positions, e.g. board members or coaches. Hence, the question arises to what extent volunteer related factors, like the workload as well as the specific position as volunteer, influence volunteer satisfaction.

Socio-demographic factors are rarely discussed in research on volunteer satisfaction. However, Bang (2015) found that age has a moderating effect on the relationship between working conditions and job satisfaction. Younger volunteers reported higher levels of job satisfaction than older volunteers when they had higher levels of respect for their knowledge, competence, and skills as leaders. This aligns with the findings that younger volunteers pursue more skill, qualification and network oriented motives and regard volunteering as an appropriate way to invest in their own human and social capital (Nichols \& Ralston, 2016; Wollebæk, Skirstad \& Hanstad, 2014). In contrast, Kulik (2007) showed a positive correlation between age and volunteer satisfaction, whereas Swierzy et al. (2018) found no age effects on volunteer engagement. Although the literature review suggests that age and gender might play a minor role for volunteer satisfaction, we integrated both factors as control variables and thus 
the following research question will be analyzed additionally: How far are gender and age relevant factors for the satisfaction of volunteers in sports clubs?

The current literature shows that paid staff and paid management could have a positive effect on volunteer satisfaction, as volunteers are supported in facing complex tasks (Papadimitriou, 1999; Sharpe, 2006).This is particularly relevant if the club has a defined person - paid or volunteer - who is explicitly responsible for volunteer management. Paid staff - as a form of professionalization - could, however, have a negative impact on volunteer satisfaction if volunteers face higher formalization and expectations while losing influence and recognition (Flatau, 2009; Seippel, 2010). Moreover, organizational characteristics such as club size have been found to be important (e.g. Harman \& Doherty, 2014; Johnson et al., 2017). Nichols and James (2008) found that club size correlates positively with professionalization, as measured by 21 practices, including having a written volunteer policy. However, the relationship between club professionalization and volunteer satisfaction has been found to be weak. Hence, the present study aims to analyze the role of selected organizational factors by investigating the following research question: how far are the following club characteristics relevant for volunteer job satisfaction in sports clubs: paid staff and management, having a responsible person for volunteer management, club size?

\section{Method and data}

Sample

The empirical analysis is based on data from the SIVSCE project, which is the first to collect comparative data on both European sports clubs and their members with a particular focus on volunteering and social integration (Elmose-Østerlund et al., 2016). Ten countries have participated in the project, including Belgium (Flanders), Denmark, England, Germany, Hungary, the Netherlands, Norway, Poland, Spain and Switzerland. The countries were selected as representative of different European regions (North-South-East-West-Central Europe), 
sports policy systems (with more or less generous funding schemes, demands for public funding and more or less well-developed sports infrastructures) and levels of sports (club) participation and volunteering (from relatively low participation- e.g. Hungary, Poland and Spain - to relatively high participation - e.g. Denmark, Germany, the Netherlands and Switzerland). This selection procedure allows for analysis that provide new knowledge about the possible role of the national context. Furthermore, the SIVSCE project was the first to collect large-scale data on sports clubs, members and volunteers in some of the selected countries (e.g. Hungary and Poland). In effect, the purposeful selection of these ten countries helps generate new knowledge about how individuals experience their satisfaction of volunteering in different sports clubs across ten countries with different national characteristics. To respond to this complexity, we chose a multilevel model with three levels for our analyses (e.g. Hox, 2002).

The ten countries can be considered as the macro level in our sample, but since there are fewer units (countries) on this third level than recommended for multilevel analyses, we keep our statistical models as simple as possible and do not include variables on the macro level. However, we control for variance in levels of satisfaction between countries to examine how differences in the national contexts of volunteering may influence volunteer satisfaction.

On the meso level, we conducted a ‘club survey’ where we collected organizational data on sports clubs through an online survey in the fall of 2015 in all ten countries (for details see Breuer et al., 2017). The sample of sports clubs is considered to be as closely representative of the population of sports clubs in each country as practicable. Where possible, the questionnaire was sent to populations or randomized samples of clubs from available databases (e.g. from sports organizations or federations). One representative from each club - most often the chairperson - was asked via email invitation to answer the survey questions on behalf of the entire club. The survey was conducted using appropriate translations of an English questionnaire developed by the research group, and covered topics related to volunteering, such 
as volunteer numbers, recruitment strategies and volunteer management, alongside questions on structural characteristics. A total number of 35,790 clubs replied to the survey.

From the sample of 35,790 clubs that participated in the club survey, we selected 642 clubs that were contacted by mail or telephone and asked if they would be willing to distribute a survey to the members and volunteers in the club (micro level). The reason we selected only 642 clubs was pragmatic; this selection made data collection feasible. In each selected club, a time-consuming discussion on the possibility of survey distribution among club members and volunteers occurred before data collection. As the number of invited clubs for the member survey ranged from 30 to 144 in each country (see Table 1), we cannot claim that the sample of clubs is representative of sports clubs in Europe. Rather, the sample in each country was selected to include clubs offering team sports, individual sports and semi-individual sports (e.g. tennis, badminton). In all ten countries, the sample was also selected to represent the variation according to club size (i.e. small, medium and large clubs), degree of urbanization (i.e. clubs from rural and urban areas), and single-sport clubs vs. multisport clubs. The 'member survey' was implemented in the spring of 2016 among all adult (16+ years) members and volunteers in all selected sports clubs (for details see van der Roest et al., 2017). The data collection took place through an online survey sent directly to members and volunteers or via club representatives. This survey study also used translations from an English questionnaire developed by the research group. It contained questions about volunteering, such as volunteer tasks, working hours and satisfaction with working conditions. As Table 1 shows, a total number of 13,082 members and volunteers, of which 8,131 were occasional or regular volunteers, replied to the survey. The replies from the member survey could be merged with the results from the club survey, as each member was nested in a particular club. Thus, it was possible for us to relate volunteer management practices and club characteristics (club survey) to volunteer satisfaction (member survey). 
[Table 1 Here]

\section{Data analysis and measures}

Despite a restricted amount of variance between group levels (two levels: ICC (club): 0.045; three levels: ICC (club: Country): 0.027 \& ICC (Country): 0.022), we chose to do a three-level analysis to be sure to take care of the dependencies between the different data levels. The number of units on the third level (nations) is smaller than recommended in most of the literature on multilevel modelling (Maas \& Hox, 2005; Snijders \& Bosker, 2011), but simulation studies (Stegmueller, 2013) indicate that as long as the models are relatively simple (in our case: random intercept model in club level only), the standard errors (and the estimation of confidence intervals) are within reasonable limits.

Volunteer satisfaction - the dependent variable of the study - was measured on a 5point Likert scale from 1= "very dissatisfied" to 5= "very satisfied" according to similar studies in the context of sports clubs and non-profit volunteer management (e.g. Chelladurai \& Ogasawara, 2003; Galindo-Kuhn \& Guzley, 2001; Schlesinger et al., 2013). The volunteers were asked: 'How satisfied are you with the conditions for volunteers in the club?' (see Table 2). Of the 8,131 volunteers 7,022 responded to the question on volunteer satisfaction.

\section{[Table 2 Here]}

For our measures of the conditions of volunteering, the volunteers evaluated the five dimensions with two questions for each dimension (for the items and descriptive statistics see Table 3) on a five-point Likert scale between 1 = "strongly disagree" and 5 = "strongly agree": task design, material incentives, leadership, support and recognition (according to the concept of Schlesinger et al., 2013). Thus, these responses are subjective perceptions. The results of the reliability analysis (Cronbach's $\alpha$ ) show acceptable results apart from the dimension task design (see Table 3). Since the $\alpha$-value was quite low (.37), this factor was not included in the multilevel analysis. 
For individual volunteer related factors, the workload of volunteers was operationalized as the number of hours spent on voluntary work on a yearly/seasonal basis. Furthermore, the respondents were differentiated according to whether they volunteered in the sports and training sector, i.e. as coaches or instructors, or as members of the clubs' boards. The following sociodemographic variables were included: gender and age. Age categories were differentiated to capture possible non-linearities.

Furthermore, three club characteristics were included at the organizational level: club size, whether clubs have paid employees and whether the club has a person responsible for volunteering. To avoid possible problems of outliers, club size was categorized (see table 3). Although we also based the selection of sports clubs for the member survey on criteria such as degree of urbanization and single-sport vs. multisport clubs, we did not include these as independent variables in the statistical model, as we did not find theoretical or empirical evidence that they were important predictors of volunteer satisfaction.

[Table 3 Here]

\section{Results}

We tested four models. The first is an empty model, the second contains only the evaluations of the different conditions of volunteering, the third model includes the individual level factors, while the fourth model is the complete model (Table 4). The analysis of the conditions of volunteering shows that all four dimensions are significant for volunteers' satisfaction (Table 4). The multilevel analysis demonstrates that the most relevant factor is recognition. When volunteers feel that their work is appreciated and the club honors them from time to time, this is associated with a higher satisfaction with volunteering in general. The factors leadership and support of volunteers also show significant effects for volunteer satisfaction, but the coefficients are considerably lower than for recognition with somewhat higher values for the 
factor support. Thus, supporting volunteers by taking their concerns seriously and giving support from other members are important for satisfaction. Material incentives (e.g. fringe benefits) are also significantly and positively related to volunteer satisfaction, but with a considerably lower effect size than can be identified for the other organizational factors.

[Table 4 Here]

A closer look at the volunteer related individual factors shows that volunteers who spend more than 300 hours per year/season on voluntary work are less satisfied than volunteers with a smaller workload. There are no significant differences between volunteers with a very little workload (10 hours or less per year/season) and the volunteers who engage between 11 and 300 hours per year/season. No effects can be observed for the position as coach or instructor or as board member. Volunteers in fixed positions as trainers or board members are as satisfied as volunteers in other positions that are usually connected with less workload and accountability.

The analysis of socio-demographic factors shows no significant difference in satisfaction for gender. Regarding age, we find that in particular the 'middle' age groups (2635, 36-45, 46-55, 56-65 years) are significantly less satisfied compared to the youngest age group (up to 25 years). The group of volunteers aged 36-45 years seems to be the least satisfied group compared with the youngest age group. There are no significant differences between the youngest and the oldest age group (66 years and older).

Finally, we focused on the relevance of club characteristics for volunteer satisfaction. The size of the club has no significant effect on the satisfaction of volunteers. Members in small clubs show the same satisfaction as members in large clubs. There is also no significant difference in volunteer satisfaction between volunteers in clubs with and without paid staff/management and with or without a responsible person for volunteering. 


\section{Discussion}

Based on actor-theory concepts that emphasize the interrelation of social structures and social action (Giddens, 1984) as well as a multi-level framework (Schlesinger \& Nagel, 2013) our study analyzed individual and organizational factors of volunteer satisfaction simultaneously. According to the concept of logic of situation (Esser, 1993) the findings show that the perceived conditions of volunteering are the most significant determinants of volunteer satisfaction in sports clubs, whereas other individual and structural factors are less relevant. There are also some effects of socio-demographic and volunteer-related factors, while club characteristics have no significant effect on the satisfaction of volunteers. The high relevance of individual determinants could be interpreted in line with trends towards fragmentation and individualization in modern societies. Furthermore, the results demonstrate that there is only small variance on the country level. Thus, it can be assumed that similar factors are relevant for volunteer satisfaction in sports clubs across the ten different European countries.

Some results confirm the existing knowledge about factors of volunteer satisfaction, however there are also some surprising findings that are not in line with the current literature. The results show a positive correlation between the evaluation of the specific conditions for volunteering in the club and satisfaction (see also e.g. Harman \& Doherty, 2014, Nencini et al., 2016; Schlesinger et al., 2013). Recognition was the most important driver of volunteer job satisfaction (e.g. Dwiggins-Beeler, et al., 2011; Farell et al., 1998). As voluntary activities are undertaken freely and without payment or with only a symbolic reimbursement of costs (Ibsen, 1992; Elmose-Østerlund et al., 2016), other rewards that outweigh their personal effort and the sacrifice of their free time are necessary. In this sense, volunteering can be conceptualized as a leisure activity distinguished from paid work by a different set of rewards and greater freedom (Nichols, Holmes, \& Baum, 2013; Nichols, 2017). However, material incentives were positively associated with volunteer satisfaction in our study, too. However, material incentives (e.g. fringe benefits) play a less important role than other conditions for volunteering with 
regard to volunteer satisfaction and sport volunteers are predominantly motivated by a shared enthusiasm for the sport, social relationships and career factors (e.g. Johnson et al., 2017; Nichols, 2017). The results emphasize the importance of a cooperative leadership and support for volunteers' satisfaction (Hobson \& Heler, 2007). Those volunteers who receive constructive feedback and help from the club management in case of any problems seem to be more satisfied (see also Stukas et al., 2016). The results suggest that support from and communication with other members also has a positive impact on volunteer satisfaction (Farell et al., 1998).

Furthermore, the results demonstrate that volunteers with a fairly high workload of more than 300 hours per year/season are less satisfied than those who have a lower voluntary workload, probably because their engagement is quite time-consuming and sometimes stressful. This is in contrast to existing findings (e.g. Dulin et al., 2012; Finkelstein, 2008) who showed a (weak) positive correlation between volunteer workload and satisfaction (see also Pauline, 2011) The position of a volunteer, e.g. coach or board member is not relevant for volunteer satisfaction; although these volunteers are the ones who have the highest workload (Nichols, 2017).

There is no relationship between gender and volunteer satisfaction (e.g. Schlesinger et al., 2013). Besides, we found an age effect, i.e. young volunteers under 25 years and those who are older than 65 years are more satisfied with their voluntary engagement compared with the other age groups (see also Bang, 2015). The reason for this could be that these age groups are less involved in responsible positions with a high accountability and workload or that the more qualification and network oriented motives of younger volunteers are better fulfilled (see Nichols \& Ralston, 2016; Wollebæk et al., 2014). Furthermore, the lower satisfaction in the middle-age groups could also be related to higher demands and stress in other areas of life.

The existing literature shows that paid staff could have a positive (e.g. Papadimitriou, 1999; Sharpe, 2006) or a negative impact on volunteer satisfaction (Flatau, 2009). However, our results demonstrate that there is neither a positive nor a negative effect of paid staff for 
volunteer satisfaction. Thus, the findings contradict the popular assumption that the employment of paid staff could endanger the satisfaction of volunteers because of higher expectations and lower influence and recognition . However, we only analyzed whether a club had paid staff and not the exact number of paid staff compared to volunteers (see also Vos et al., 2012). Furthermore, the structural factor club size that refers to different organizational conditions of sports clubs did not show a significant effect on volunteer satisfaction, in contrast to other studies (e.g. Nichols \& James, 2008). One explanation for this unexpected result may be that larger clubs are often divided into sections that offer similar working conditions and support for volunteers as smaller clubs. Another explanation could be that larger sports clubs have greater implementation of measures and positions to compensate for the less attractive conditions. In this context the question arises if having a person responsible for volunteering in a sports club corresponds with a higher satisfaction of volunteers. However, there is also no impact for this specific measure of volunteer management. One explanation for this unexpected result might be that such a position is only established in clubs that have problems to recruit enough volunteers and thus have to improve the volunteer management. Further, it is possible that many clubs have a volunteer who takes responsibility for coordinating others, but this is not a formal role. Here, it can be hypothesized that all clubs succeed relatively well in promoting volunteering whether they have specific formalized positions or not.

\section{Limitations and further research}

The volunteers included in this study were recruited from a selection of 642 sports clubs in ten European countries. These clubs represent a significant aspect of sports clubs variation according to the sports activity and selected structural characteristics (club size, degree of urbanization and single-sport vs. multisport clubs), but cannot be expected to represent European sports clubs. Accordingly, the results should be interpreted with some caution. A 
concrete example is the satisfaction of volunteers (Table 2), which may not accurately reflect the satisfaction level of volunteers in European sports clubs.

When considering the surveyed volunteers, it should be noted that the literature on survey design has clearly established that people with a strong interest in the topic(s) are more likely to reply to that particular survey (Fowler, 2014; Groves et al., 2009). Since the member survey was framed according to the topics of social integration and volunteering, it is likely that more socially integrated members and engaged volunteers (e.g. in fixed positions, with longstanding affiliation and a relatively high time use) were more willing to complete the survey than those less engaged. When specifically considering volunteer satisfaction, it can be assumed that both more satisfied and less satisfied volunteers are part of the sample, as even strongly engaged volunteers may not be satisfied with the conditions for volunteering in their club. However, only $9 \%$ of volunteers surveyed are dissatisfied. Here, it can be assumed that other dissatisfied volunteers have terminated their volunteer engagement. Despite potential bias, we have also considered a (smaller) sub-sample of dissatisfied volunteers in our study.

The sample of volunteers mainly contains answers from respondents that have completed the survey, but some respondents have only partially answered the questionnaire or have skipped some questions. As a result, all survey items contain some rate of item nonresponse. The non-response rates were around 15\% for volunteer conditions and satisfaction. There were no items with particularly high non-response rates for the other variables included in the multilevel analysis. Furthermore, when we tested different ways of dealing with missing values in the statistical analysis, we did not find significant differences in the results.

As the data collection took place in ten different countries, concepts and questionnaires originally worded in English had to be translated into the appropriate language. This procedure could potentially have an impact on the comprehension and meaning of certain questions. This is likely to be more of an issue for attitudinal questions rather than factual ones. In order to 
mitigate this, the most ambiguous words were elaborated using an explanation or an example (e.g. 'reduced membership fee' as an example for 'fringe benefits').

Although the findings can be cautiously generalized to sports clubs in different (European) countries, further research might identify the relevance of specific national characteristics. For example, the concept of volunteering itself is socially constructed and may vary between countries with regard to the relationship to personal reward and provision of services by the state. The innovative multilevel approach developed in our study could be used for such research. Besides, more aspects of professionalization of sports clubs apart from paid staff (e.g. strategic planning, formalized volunteer management) could be considered on the organizational level in further studies. Furthermore, one could look at current values and attitudes of volunteer in order to capture possible effects of modernization and individualization. In this context, further research could more deeply focus on the conditions for volunteering in clubs, possibly through in-depth qualitative studies in clubs. This would provide more details on the factors and mechanism influencing volunteer satisfaction, and their connection to societal conditions and developments.

\section{Conclusion}

The background for this study are general shifts in society, particularly individualization (e.g. Putnam, 2000) and consumerism (e.g. Shrubsole, 2012). These developments could affect the willingness of people to volunteer in sports clubs. The results of this first multilevel analysis of volunteer satisfaction could serve as a basis for successful volunteer management in the challenging situation for sports clubs in modern societies, since volunteer satisfaction is a crucial factor for volunteer recruitment and retention (Schlesinger et al., 2013, 2017). The findings provide insight into useful measures to maintain and enhance satisfaction of volunteers in sports clubs and thus promote positive attitudes towards volunteering in order to strengthen 
active citizenship and democratic participation. It can be assumed that voluntary sports clubs regardless of their size, whether they have paid staff or a coordinator for volunteers, or their national context, can become more successful in their retention of volunteers, and possibly recruitment, if they give special and reinforced focus to volunteer recognition, volunteer support and leadership. Here, it is important that the specific measures are evaluated positively by the volunteers and thus lead to satisfaction. As voluntary work can give members the opportunity to gain experience in active citizenship and thus promote social cohesion, sports clubs should consider measures to enhance recognition and leadership as very important factors for all of their volunteers. However, possible material incentives should also play a role in volunteer management, at the risk of crowding out altruistic motives. Similarly, guidance and support gain a higher level of importance when it comes to problematic situations as they assist volunteers to stay competent in what they do and provide satisfaction in helping others and being effective in problem solving. Furthermore, the workload of a single volunteer should be limited, and the tasks divided between several volunteers. 


\section{References}

Bang, H. (2015). Volunteer age, job satisfaction, and intention to stay. Leadership \& Organization Development Journal, 36(2), 161-176.

Behrens, C., Emrich, E., Meyer, T. \& Pierdzioch, C. (2016). Football clubs and philantropy: an empirical analysis of volunteering, match quality, and donations. International Review for the Socialogy of Sport, 53(5), 594-614. doi: $\underline{10.1177 / 1012690216672653}$

Blackman, D. A. \& Benson, A. M. (2010). The Role of the Psychological Contract in Managing Research Volunteer Tourism. Journal of Travel \& Tourism Marketing, 27(3), 221-235.

Breuer, C., Feiler, S., Llopis-Goig, R., Elmose-Østerlund, K., Bürgi, R., Claes, E. et al. (2017). Characteristics of European sports clubs. A comparison of the structure, management, voluntary work and social integration among sports clubs across ten European countries. Odense: University of Southern Denmark.

Chelladurai, P. (2006). Human Resource Management in Sport and Recreation (2nd ed.). Human Kinetics: Champaign, IL.

Chelladurai, P. \& Ogasawara, E. (2003). Satisfaction and Commitment of American and Japanese Collegiate Coaches. Journal of Sport Management, 17(1), 63-73.

Coleman, J. S. (1986). Social Theory, Social Research, and a Theory of Action. American Journal of Sociology, 91, 1309-1335.

Costa, C. A., Chalip, L., Christine Green, B. \& Simes, C. (2006). Reconsidering the Role of Training in Event Volunteers’ Satisfaction. Sport Management Review, 9(2), 165-182.

Doherty, A. (2005). Volunteer Management in Community Sport Clubs: A Study of Volunteers` Perception. Parks and Recreation Ontario and the Sport Alliance of Ontario: Toronto.

Dulin, P. L., Gavala, J., Stephens, C., Kostick, M. \& McDonald, J. (2012). Volunteering predicts happiness among older Maori and non-Maori in the New Zealand health, work, and retirement longitudinal study. Aging \& mental health, 16(5), 617-624. 
Dwiggins-Beeler, R., Spitzberg, B., \& Roesch, S., (2011). Vectors of volunteerism: Correlates of volunteer retention, recruitment, and job satisfaction. Journal of Psychological Issues in Organizational Culture 2(3), 22-43.

Elmose-Østerlund, K., Ibsen, B., Breuer, C., Feiler, S., Llopis-Goig, R., Nagel, S. et al. (2016). Introduction to the project "Social inclusion and volunteering in sports clubs Europe" (SIVSCE). Odense: University of Southern Denmark.

Elmose-Østerlund, K., Seippel, Ø., Llopis-Goig, R., van der Roest, J.-W., Adler Zwahlen, J., \& Nagel, S. (2019). Social Integration in Sports Clubs: Individual and Organisational factors in a European context. European Journal for Sport and Society. Advance online publication. DOI: 10.1080/16138171.2019.1652382

Esser, H. (1993). Soziologie. Allgemeine Grundlagen. [Sociolgy. General fundamentals.]. Frankfurt am Main: Campus.

Einolf, C. (2018). Evidence-based volunteer management: a review of the literature. Volunteer Sector Review, 9 (2), 153-176.

Farrell, J. M., Johnston, M. E. \& Twynam, G. D. (1998). Volunteer Motivation, Satisfaction, and Management at an Elite Sporting Competition. Journal of Sport Management, 12(4), 288-300.

Finkelstein, M. A. (2008). Volunteer Satisfaction and Volunteer Action: A Functional Approach. Social Behavior and Personality, 36(1), 9-18.

Flatau, J. (2009). Zum Zusammenhang von Sozialisation und ehrenamtlicher Mitarbeit in Sportvereinen - Erste Überlegungen unter Anwendung der Rational-Choice-Theorie. [The relation of socialisation and voluntary work in sports clubs - first considerations using the rational choice theory.]. Sport und Gesellschaft, 6(3), 259-282.

Fowler, F.J. (2014). Survey research methods. Thousand Oaks, California: SAGE. 
Galindo-Kuhn, R. \& Guzley, R. M. (2001). The Volunteer Satisfaction Index: Construct Definition, Measurement, Development, and Validation. Journal of Social Service Research, 28(1), 45-68.

Giddens, A. (1984). The constitution of society. Cambridge, MA: Polity press.

Groves, R.M., Fowler, F.J., Couper, M.P., Lepkowski, J.M., Singer, E., \& Tourangeau, R. (2009). Survey methodology. Hoboken, New Jersey: John Wiley \& Sons, Inc.

Harman, A. \& Doherty, A. (2014). The Psychological Contract of Volunteer Youth Sport Coaches. Journal of Sport Management, 28(6), 687-699.

Hobson, C.J., \& Heler, K., (2007). The importance of initial assignment quality and staff treatment of new volunteers: A field test of the Hobson-Heler model of nonprofit agency ‘volunteer-friendliness’. International Journal of Volunteer Administration 14(6), 4756.

Hox, J. J. (2002). Multilevel analysis: Techniques and applications. Lawrence Erlbaum: Mahwah, NJ.

Ibsen, B. (1992). Frivilligt arbejde i idrcetsforeninger [Voluntary work in sports clubs]. DHL: Copenhagen.

Ibsen, B., Elmose-Østerlund, K., Feiler, S., Breuer, C., Seippel, Ø., van der Roest, J.-W., \& Scheerder, J. (2019). Democratic Participation in Voluntary Associations: A Multilevel Analysis of Sports Clubs in Europe. VOLUNTAS: International Journal of Voluntary and Nonprofit Organizations. Advance online publication.

Janssens, J., \& Verweel, P. (2014). The significance of sports clubs within multicultural society. On the accumulation of social capital by migrants in culturally "mixed" and "separate” sports clubs. European Journal for Sport and Society, 11(1), 35-58.

Johnson, J. E., Giannoulakis, C., Felver, N., Judge, L. W., David, P. A. \& Scott, B. F. (2017). Motivation, Satisfaction, and Retention of Sport Management Student Volunteers. Journal of Applied Sport Management, 9(1). doi: 10.18666/jasm-2017-v9-i1-7450 
Kulik, L. (2007). Explaining responses to volunteering: An ecological model. Nonprofit and Voluntary Sector Quarterly 36(2), 239-55.

Locke, E. A. (1969). What is Job Satisfaction?. Organizational Behavior and Human Performance, 4(4), 309-336.

Maas, C. J. \& Hox, J. J. (2005). Sufficient Sample Sizes for Multilevel Modeling. Methodology, 1(3), 86-92.

Nagel, S. (2007). Akteurtheoretische Analyse der Sportvereinsentwicklung - Ein theoretischmethodischer Bezugsrahmen. [Actor-theoretical analysis of sports clubs development A theoretical and methodological frame of reference.]. Sportwissenschaft, 37, 186-201.

Nagel, S., Schlesinger, T., Wicker, P., Lucassen, J., Hoekman, R., van der Werff, H. et al. (2015). Theoretical framework. In C. Breuer, R. Hoekman, S. Nagel \& H. van der Werff (Eds.), Sport clubs in Europe. A cross-national comparative perspective (pp. 7-27). New York, Heidelberg, London: Springer.

Nencini, A., Romaioli, D., \& Meneghini, AM. (2016). Volunteer motivation and organizational climate: Factors that promote satisfaction and sustained volunteerism in NPOs. Voluntas 27, 618-39.

Nichols, G. (2017). Volunteering in Community Sports Associations. Leiden: Koninklijke Brill. Nichols, G., Holmes K. \& Baum, T. (2013). Volunteering as leisure; leisure as volunteering. In T. Blackshaw (Eds.), The Routledge International Handbook of Leisure Studies (pp. 456-467). London: Routledge.

Nichols, G. \& James, M. (2008). One size does not fit all: implications of sports club diversity for their effectiveness as a policy tool and for government support. Managing Leisure, 13(2), 104-114. 
Nichols, G. \& Ralston, R. (2016). Talking about my generation: generational differences in the attitudes of volunteers at the 2012 Olympic Games. Voluntary Sector Review, 7(2), 127147.

Østerlund, K., and Seippel, Ø. (2013). Does membership in civil society organizations foster social integration? The case of Danish voluntary sport organizations. Journal of Civil Society 9(4), 1-23.

Papadimitriou, D. (1999). Voluntary Boards of Directors in Greek Sport Governing Bodies. European Journal for Sport Management, 6, 78-103.

Pauline, G. (2011). Volunteer Satisfaction and Intent to Remain: An Analysis of Contributing Factors Among Professional Golf Event Volunteers. International Journal of Event Management Research, 6(1), 10-32.

Putnam, R. D. (2000). Bowling alone: the collapse and revival of American community. New York: Simon \& Schuster.

Schlesinger, T., Egli, B. \& Nagel, S. (2013). ‘Continue or terminate?’ Determinants of longterm volunteering in sports clubs. European Sport Management Quarterly, 13(1), 3253.

Schlesinger, T., Egli, B. \& Nagel, S. (2017). Determinants of stable volunteering in Swiss soccer clubs. Soccer \& Society, 18, 1-17. doi: 10.1080/14660970.2017.1355789

Schlesinger, T., Klenk, C. \& Nagel, S. (2014). Freiwillige Mitarbeit im Sportverein. Analyse individueller Faktoren und organisationaler Entscheidungen. [Volunteering in sports clubs. Analysis of individual factors and organizational decisions.] Zürich: Seismo.

Schlesinger, T. \& Nagel, S. (2013). Who will volunteer? Analysing individual and structural factors of volunteering in Swiss sports clubs. European Journal of Sport Science, 13, 707-715. doi: 10.1080/17461391.2013.773089 
Schlesinger, T., \& Nagel, S. (2018). Individual and contextual determinants of stable volunteering in sport clubs. International Review for the Sociology of Sport, 53(1), 101121.

Seippel, Ø. (2005). Sport, civil society and social integration: The case of Norwegian voluntary sport organizations. Journal of Civil Society, 1(3), 247-265.

Seippel, Ø. (2010). Professionals and volunteers: on the future of a Scandinavian sport model. Sport in Society, 13(2), 199-211. doi:10.1080/17430430903522921

Sharpe, E. K. (2006). Resources at the Grassroots of Recreation: Organizational Capacity and Quality of Experience in a Community Sport Organization. Leisure Sciences, 28(4), 385-401.

Shrubsole, G. (2012). Consumers outstrip citizens in the British media. London: Open Democracy.

Snijders, T. \& Bosker, R. (2011). Multilevel Analysis: An Introduction to Basic and Advanced Multilevel Modeling. London: Sage.

Stegmueller, D. (2013). How Many Countries for Multilevel Modeling? A Comparison of Frequnetist and Bayesian Approaces. American Journal of Political Science, 57(3), 748761.

Stukas, A. A., Hoye, R., Nicholson, M., Brown, K. M. \& Aisbett, L. (2016). Motivations to Volunteer and Their Associations With Volunteers' Well-Being. Nonprofit and Voluntary Sector Quarterly, 45(1), 112-132.

Swierzy, P., Wicker P. \& Breuer, C. (2018). The impact of organizational capacity on voluntary engagement in sports clubs: A multi-level analysis. Sport Management Review 21, 307320.

Van der Roest, J.-W., van der Werff, H., Elmose-Østerlund, K., Albrecht, J., Breuer, C., Claes, E. et al. (2017). Involvement and commitment of members and volunteers in European 
sports clubs. A comparison of the affiliation, voluntary work, social integration and characteristics of members and volunteers in sports clubs across ten European countries. Odense: University of Southern Denmark.

Vecina, M. L., Chacón, F., Sueiro, M. \& Barrón, A. (2012). Volunteer Engagement: Does Engagement Predict the Degree of Satisfaction among New Volunteers and the Commitment of Those who have been Active Longer? Applied Psychology: An International Review, 61(1), 130-148.

Vos, S., Breesch, D, Késenne, S., Lagae, W., Van Hoecke, J., Vanreusel, B. \& Scheerder, J. (2012). The value of human resources in non-public sports providers. The importance of volunteers in non-profit sports clubs versus professionals in for-profit fitness and health clubs. International Journal of Sport Management \& Marketing 11(1+2): 3-25.

Warren, M. E. (2001). Democracy and Association. Princeton: Princeton University Press.

Wicker, P. \& Hallmann, K. (2013). A multi-level framework for investigating the engagement of sport volunteers. European Sport Management Quarterly, 13(1), 110-139.

Wilson, J. (2012). Volunteerism Research: A Review Essay. Nonprofit and Voluntary Sector Quarterly, 41(2), 176-212.

Wollebæk, D., Skirstad, B., \& Hanstad, D. V. (2014). Between two volunteer cultures: Social composition and motivation among volunteers at the 2010 test event for the FIS Nordic World Ski Championships. International Review for the Sociology of Sport, 49(1), $122-$ 141. 


\section{Tables}

Table 1

The number of clubs selected and the number of responses from members and volunteers obtained in the member surveys in the ten countries.

\begin{tabular}{|c|c|c|c|}
\hline Country & $\begin{array}{l}\text { Number of } \\
\text { clubs }\end{array}$ & $\begin{array}{l}\text { Number of } \\
\text { responses of } \\
\text { members }\end{array}$ & $\begin{array}{l}\text { Number of } \\
\text { volunteers }\end{array}$ \\
\hline Belgium (Flanders) & 47 & 762 & 468 \\
\hline Denmark & 36 & 3,163 & 1,429 \\
\hline England & 40 & 717 & 538 \\
\hline Germany & 141 & 2,455 & 1,688 \\
\hline Hungary & 47 & 716 & 426 \\
\hline The Netherlands & 144 & 1,965 & 1,403 \\
\hline Norway & 30 & 1,330 & 1,030 \\
\hline Poland & 61 & 570 & 289 \\
\hline Spain & 55 & 445 & 322 \\
\hline Switzerland & 41 & 959 & 538 \\
\hline Total & 642 & 13,082 & 8,131 \\
\hline
\end{tabular}


Table 2

Descriptive statistics for the dependent variable included in the analyses.

\begin{tabular}{lll}
\hline Dependent variable & $\begin{array}{l}\text { Percentage } \\
(\mathbf{\%})\end{array}$ & $\begin{array}{l}\text { Total } \\
\text { number of } \\
\text { replies (N) }\end{array}$ \\
& & 7,022 \\
\hline Volunteer satisfaction & 5 & \\
1: Very dissatisfied & 4 & \\
2: Dissatisfied & 21 & \\
3: Neither dissatisfied nor satisfied & 54 & \\
4: Satisfied & 16 & \\
5: Very satisfied & & \\
\hline
\end{tabular}


Table 3

Descriptive statistics for the independent variables included in the analyses.

\begin{tabular}{|c|c|c|c|}
\hline Independent variables & $\begin{array}{l}\text { Average } \\
\text { (Std. } \\
\text { deviation) }\end{array}$ & $\begin{array}{l}\text { Percentage } \\
(\%)\end{array}$ & $\begin{array}{l}\text { Total } \\
\text { number of } \\
\text { replies (N) }\end{array}$ \\
\hline \multicolumn{4}{|c|}{ Organizational factors: (perceived) conditions for volunteering } \\
\hline Task design: $(\alpha=.37)$ (excluded from the analysis) & $3.93(0.85)$ & & 6,370 \\
\hline (1) tasks are interesting and challenging & $3.99(1.02)$ & & 6,631 \\
\hline (2) carrying out work autonomously & $3.87(0.98)$ & & 6,503 \\
\hline Material incentives: $(\alpha=.56)$ & $1.99(1.17)$ & & 6,261 \\
\hline (1) getting fringe benefits & $2.17(1.49)$ & & 6,399 \\
\hline (2) getting some payment for volunteer work & $1.86(1.33)$ & & 6,466 \\
\hline Leadership: $(\alpha=.61)$ & $3.55(1.05)$ & & 6,185 \\
\hline $\begin{array}{l}\text { (1) constructive feedback from club } \\
\text { management }\end{array}$ & $3.26(1.29)$ & & 6,345 \\
\hline (2) information about major club affairs & 3.85 (1.19) & & 6,511 \\
\hline Support: $(\alpha=.63)$ & $3.81(0.92)$ & & 5,886 \\
\hline (1) problems and concerns are taken seriously & $3.74(1.09)$ & & 6,109 \\
\hline (2) support from other club members & $3.88(1.07)$ & & 6,358 \\
\hline Recognition: $(\alpha=.66)$ & $3.93(0.97)$ & & 6,239 \\
\hline (1) work is appreciated & $3.99(1.02)$ & & 6,623 \\
\hline (2) club honors volunteer work & $3.67(1.26)$ & & 6,369 \\
\hline
\end{tabular}

\section{Individual volunteer related factors}

\begin{tabular}{lll}
\hline Workload of volunteering (hours per year/season; & \\
categorized) & 19 & \\
1: up to 10 & 26 & \\
2: $11-50$ & 26 & \\
3: $51-150$ & 15 & \\
4: $151-300$ & 14 & \\
5: 301 or more & & \\
Volunteering as coach or instructor & 71 & \\
1: no & 29 & \\
2: yes & & \\
Volunteering as board member & 80 & \\
1: no & 20 & \\
2: yes & & \\
\hline Individual socio-demographic factors & & \\
\hline Gender & 38 & \\
1: woman & 62 & \\
2: man & & 6,716 \\
Age (categorized) & 15 & \\
1: up to 25 years & 12 & \\
2: $26-35$ years & 21 & \\
3: $36-45$ years & 25 & \\
4: $46-55$ years & 15 & \\
5: $56-65$ years & & \\
\hline
\end{tabular}


Organizational factors: club characteristics

Club size (number of members; categorized)

7,848

1: up to 100

14

2: $101-250$

23

3: $251-500$

25

4: $501-1500$

21

5: 1501 or more

17

Paid employees

7,586

1: no

85

2: yes

15

Responsible person for volunteering

1: no

78

2: yes

8,119

22 
Table 4

Results of the three level multilevel analyses (random intercept; non-standardized coefficients; standard errors).

\begin{tabular}{|c|c|c|c|}
\hline \multicolumn{4}{|c|}{ Dependent Variable } \\
\hline Models & $(2)$ & (3) & (4) \\
\hline $\begin{array}{l}3.747 * * * \\
(0.048)\end{array}$ & $\begin{array}{c}2.338 * * * \\
(0.073)\end{array}$ & $\begin{array}{l}2.447 * * * \\
(0.088)\end{array}$ & $\begin{array}{c}2.464 * * * \\
(0.099)\end{array}$ \\
\hline \multicolumn{4}{|c|}{ Organizational factors: (perceived) conditions for volunteering } \\
\hline Material incentives & $\begin{array}{l}0.025^{* *} \\
(0.011)\end{array}$ & $\begin{array}{l}0.027^{* *} \\
(0.013)\end{array}$ & $\begin{array}{c}0.029 * * \\
(0.013)\end{array}$ \\
\hline Leadership & $\begin{array}{c}0.075^{* * *} \\
(0.017)\end{array}$ & $\begin{array}{c}0.081 * * * \\
(0.018)\end{array}$ & $\begin{array}{c}0.086^{* * *} \\
(0.019)\end{array}$ \\
\hline Support & $\begin{array}{c}0.098 * * * \\
(0.021)\end{array}$ & $\begin{array}{c}0.107 * * * \\
(0.022)\end{array}$ & $\begin{array}{c}0.100^{* * *} \\
(0.022)\end{array}$ \\
\hline Recognition & $\begin{array}{c}0.181^{* * *} \\
(0.018)\end{array}$ & $\begin{array}{c}0.176^{* * *} \\
(0.019)\end{array}$ & $\begin{array}{c}0.180^{* * *} \\
(0.020)\end{array}$ \\
\hline \multicolumn{4}{|l|}{ Individual volunteer related factors } \\
\hline $\begin{array}{l}\text { Workload } \\
\text { volunteering 11-50 } \\
\text { hours (contrast 0-10 } \\
\text { hours) }\end{array}$ & & $\begin{array}{c}-0.041 \\
(0.044)\end{array}$ & $\begin{array}{c}-0.053 \\
(0.045)\end{array}$ \\
\hline $\begin{array}{l}\text { Workload } \\
\text { volunteering 51-150 } \\
\text { hours } \\
\end{array}$ & & $\begin{array}{c}-0.057 \\
(0.045)\end{array}$ & $\begin{array}{l}-0.067 \\
(0.047)\end{array}$ \\
\hline $\begin{array}{l}\text { Workload } \\
\text { volunteering 151-300 } \\
\text { hours }\end{array}$ & & $\begin{array}{c}-0.048 \\
(0.051)\end{array}$ & $\begin{array}{l}-0.054 \\
(0.052)\end{array}$ \\
\hline $\begin{array}{l}\text { Workload } \\
\text { volunteering } 301+ \\
\text { hours }\end{array}$ & & $\begin{array}{c}-0.114^{* *} \\
(0.053)\end{array}$ & $\begin{array}{c}-0.121^{* *} \\
(0.055)\end{array}$ \\
\hline Volunteering at board & & $\begin{array}{c}0.027 \\
(0.034)\end{array}$ & $\begin{array}{c}0.025 \\
(0.035)\end{array}$ \\
\hline Volunteering as coach & & $\begin{array}{c}0.001 \\
(0.031)\end{array}$ & $\begin{array}{l}-0.004 \\
(0.033)\end{array}$ \\
\hline \multicolumn{4}{|c|}{ Individual socio-demographic factors } \\
\hline Gender & & $\begin{array}{c}0.009 \\
(0.028)\end{array}$ & $\begin{array}{c}0.012 \\
(0.029)\end{array}$ \\
\hline $\begin{array}{l}\text { Age 26-35 (contrast } \\
\text { age 16-25) }\end{array}$ & & $\begin{array}{c}-0.137 * * * \\
(0.050)\end{array}$ & $\begin{array}{c}-0.159 * * * \\
(0.052)\end{array}$ \\
\hline Age 36-45 & & $\begin{array}{c}-0.213^{* * *} \\
(0.045) \\
\end{array}$ & $\begin{array}{c}-0.235 * * * \\
(0.047)\end{array}$ \\
\hline Age 46-55 & & $\begin{array}{c}-0.143^{* * *} \\
(0.045)\end{array}$ & $\begin{array}{c}-0.164 * * * \\
(0.047)\end{array}$ \\
\hline Age 56-65 & & $\begin{array}{c}-0.111^{* *} \\
(0.051)\end{array}$ & $\begin{array}{c}-0.128^{* *} \\
(0.053)\end{array}$ \\
\hline Age $66+$ & & 0.054 & 0.027 \\
\hline
\end{tabular}




\begin{tabular}{|c|c|c|c|c|}
\hline & & & $(0.059)$ & $(0.061)$ \\
\hline \multicolumn{5}{|c|}{ Organizational factors: club characteristics } \\
\hline $\begin{array}{l}\text { Club size } 101-250 \\
\text { (contrast } 0-100 \text { ) }\end{array}$ & & & & $\begin{array}{l}-0.010 \\
(0.050)\end{array}$ \\
\hline Club size $251-500$ & & & & $\begin{array}{c}0.004 \\
(0.051)\end{array}$ \\
\hline Club size 501-1500 & & & & $\begin{array}{c}0.020 \\
(0.056)\end{array}$ \\
\hline Club size $1501+$ & & & & $\begin{array}{l}-0.022 \\
(0.067)\end{array}$ \\
\hline Paid employees & & & & $\begin{array}{c}0.039 \\
(0.050)\end{array}$ \\
\hline $\begin{array}{l}\text { Responsible person } \\
\text { for volunteers }\end{array}$ & & & & $\begin{array}{l}-0.035 \\
(0.041)\end{array}$ \\
\hline $\begin{array}{l}\text { Var( 1|club x } \\
\text { Country) }\end{array}$ & 0.025 & 0.016 & 0.011 & 0.011 \\
\hline $\operatorname{Var}(\sim 1 \mid$ Country $)$ & 0.020 & 0.014 & 0.014 & 0.016 \\
\hline Observations & 7,022 & 5,280 & 4,791 & 4,593 \\
\hline Log Likelihood & $-9,612.311$ & $-6,999.826$ & $-6,315.493$ & $-6,098.649$ \\
\hline AIC & $19,232.620$ & $14,015.650$ & $12,670.990$ & $12,249.300$ \\
\hline BIC & $19,260.050$ & $14,068.230$ & $12,800.480$ & $12,416.540$ \\
\hline
\end{tabular}

Note. ${ }^{*} \mathrm{p}<0.1 ;{ }^{* *} \mathrm{p}<0.05 ;{ }^{* * *} \mathrm{p}<0.01$; 